\title{
Loss on ignition versus thermogravimetric analysis: a comparative study to determine organic matter and carbonate content in sediments
}

\author{
Mohammed Bensharada $(D \cdot$ Richard Telford $\cdot$ Ben Stern • Vince Gaffney
}

Received: 11 September 2020/Accepted: 2 July 2021/Published online: 8 October 2021

(C) The Author(s) 2021

\begin{abstract}
Mass loss at specified temperatures has been used widely to determine amounts of organic matter and carbonate in sediment samples. The loss on ignition (LOI) method is cheap and simple, but is timeconsuming and provides information only for specific, pre-determined temperatures. It also requires relatively large sample sizes and is destructive. Thermogravimetric analysis (TGA) is an alternative method for determination of organic and carbonate content in sediment samples, and provides accurate and precise data in a time-efficient manner. We compared results from these two thermal analysis techniques, which were applied to sediment samples from a submerged landscape (Doggerland). An organic-rich peat sample and a silty fine-sand sample were used. An unpaired t-test was used to test agreement and repeatability of
\end{abstract}

M. Bensharada $(\bowtie) \cdot$ B. Stern · V. Gaffney

Faculty of Life Science, School of Archaeological and

Forensic Science, University of Bradford, Richmond

Road, Bradford BD7 1DP, UK

e-mail: m.a.m.bensharada@bradford.ac.uk

B. Stern

e-mail: b.stern@bradford.ac.uk

V. Gaffney

e-mail: v.gaffney@ bradford.ac.uk

R. Telford

Faculty of Life Science, School of Chemistry and

Biosciences, University of Bradford, Richmond Road,

Bradford BD7 1DP, UK

e-mail: r.telford@bradford.ac.uk the two analytical techniques. One advantage of being able to monitor mass loss throughout the analytical operation is that free and bound moisture losses can be distinguished. TGA is less time-consuming, involves automated sample handling (minimising operator error), and can yield reliable data from sample masses (typically 30-50 mg), which are much smaller than those needed for LOI (typically 3-5 g). The unpaired t-test, along with precision and repeatability analyses led us to conclude that TGA can be used instead of LOI to provide reliable measures of organic matter and carbonate content in sediments, and has several advantages over LOI.

Keywords Loss on ignition - Doggerland sediment · Thermogravimetric analysis $\cdot$ Multistage

\section{Introduction \\ Loss on ignition (LOI)}

Heating of samples to specified temperatures has been used widely to measure organic matter and carbonate content in sediment, soil and coal fly ash samples (Bengtsson and Enell 1986; Heiri et al. 2001; Santisteban et al. 2004). The principle that underlies the method is that the sample will lose weight at specific temperatures, reflecting loss of specific components 
from the material (Heiri et al. 2001). The standard LOI method presented by Konare et al. (2010) used three different temperatures under an air atmosphere: (1) the sample was first heated to $150{ }^{\circ} \mathrm{C}$ during which mass loss was attributed to water, (2) the temperature was next raised to $550{ }^{\circ} \mathrm{C}$ which combusts organic matter in the sample, yielding ash and carbon dioxide, and (3) the sample was finally heated to $950{ }^{\circ} \mathrm{C}$, the temperature at which carbonates were decomposed to produce carbon dioxide. Weight losses during each heating stage can be used to calculate the amount of moisture, organic matter and carbonate in the sample (Ben-Dor and Banin 1989; Santisteban et al. 2004; Heiri et al. 2001; Virkanen et al. 1997).

LOI is used widely by paleolimnologists, geochemists and sedimentologists and is an inexpensive, "low-tech" method for analysing the composition of sediment and rock samples. There are, however, some drawbacks to the approach, such as the large sample size required, typically $3-5 \mathrm{~g}$. This may consume a substantial proportion of the sample and has the associated disadvantage of requiring more time for mass loss to occur. Other considerations associated with the LOI approach include furnace type, position of samples in the furnace, exposure time at temperature, and the potential for operator error during the weighing process (Heiri et al. 2001; Fan and Brown 2001).

Thermogravimetric analysis (TGA)

TGA is an instrumental method that is used to measure sample mass as a function of time and temperature. One disadvantage of TGA instrumentation is that its relatively high cost, about four times that of LOI. Nevertheless, TGA has a number of advantages, which include: (1) speed of analysis, (2) the fact that a small sample mass can be used, (3) lower incidence of weighing errors because mass determination is automated, and most importantly, (4) the ability to monitor sample mass throughout the analysis, i.e. changes in sample weight can be tracked continuously with temperature increase (Fan and Brown 2001; Charsley et al. 2019).

We compared results from the two thermal analysis techniques (LOI and TGA), applied to a set of sediment samples from cores taken from a nowsubmerged landscape (Doggerland) (Gaffney et al. 2017). We assessed organic matter and carbonate content in the samples using both analytical approaches, and evaluated the comparability of data from the two techniques using statistical methods. Assessment of moisture composition was not an aim of this study, as the samples had been subjected to different storage, transport and air-drying histories. Complete drying of the samples is, however, an integral part of both methodologies, and is required to provide accurate measures of organic matter and carbonate content.

\section{Materials and methods}

Field sampling

Multiple sediment cores were collected on 14 September 2016 under the auspices of the Europe Lost Frontiers Project at the University of Bradford, which is studying prehistoric land now submerged under the North Sea, known as Doggerland (Gaffney et al. 2017, 2020). The cores were kept in a cold room storage environment maintained at $2{ }^{\circ} \mathrm{C} \pm 0.5$. Two bulk samples were taken from cores ELF002 and ELF009. The sample from core ELF002 was a reddish-brown, silty fine sand, which was expected to contain low organic matter content and intermediate carbonate content. The sample from core ELF009 was a very dark brown, amorphous dense peat, which was expected to contain a high percentage of organic matter. Ten subsamples were taken from each bulk sample, yielding 20 subsamples to be measured by each technique. Core names, locations, date of collection, and seafloor depth at the collection site are shown in Table 1.

\section{Laboratory analyses}

Prior to analysis, the two bulk samples $(\sim 500 \mathrm{~g}$ each) were air dried at room temperature for $48 \mathrm{~h}$ to remove the bulk water, making them easier to manipulate, homogenise and subsample. Then they were ground to fine powders in a mortar and pestle.

\section{LOI}

The method of Konare et al. (2010) was applied to 20 samples (10 samples each from cores ELF002 and ELF009). Initial sample weights were $3.00 \pm 0.01 \mathrm{~g}$. 
Table 1 Core names, locations and depths

\begin{tabular}{llll}
\hline Core name & Location X WGS84 & Location Y WGS84 & $\begin{array}{l}\text { Seafloor depth } \\
(\mathrm{m})\end{array}$ \\
\hline ELF002 & 1.1175304 & 53.321959 & 18.29 \\
ELF009 & 1.4084871 & 53.407806 & 26.19 \\
\hline
\end{tabular}

A high-temperature Carbolite furnace, which can reach $1100{ }^{\circ} \mathrm{C}$ was utilized for this analysis. Samples were placed in pre-weighed crucibles and put into the furnace at $150{ }^{\circ} \mathrm{C}$ for $2 \mathrm{~h}$, after which they were removed from the furnace and allowed to cool to room temperature in a desiccator. Once cool, they were reweighed, primarily to ensure that the samples were completely dried prior the determination of organic and carbonate content. The process was repeated at $550{ }^{\circ} \mathrm{C}$ and $950{ }^{\circ} \mathrm{C}$, and percentages of organic matter and lost $\mathrm{CO}_{2}$ were determined applying Eqs. 1 and 2, respectively. The results of the latter were expressed as total carbonate in the dry sample (by multiplying $\mathrm{CO}_{2}$ by 1.36 to express as $\mathrm{CO}_{3}$ ).

$\begin{aligned} \text { Organic } \%= & \frac{\left(\text { weight at } 150^{\circ} \mathrm{C}-\text { weight at } 550^{\circ} \mathrm{C}\right)}{\text { weight at } 150^{\circ} \mathrm{C}} \\ & \times 100 \quad \text {. }\end{aligned}$

Lost $\begin{aligned} \mathrm{CO}_{2} \%= & \frac{\left(\text { weight at } 550^{\circ} \mathrm{C}-\text { weight at } 950^{\circ} \mathrm{C}\right)}{\text { weight at } 150^{\circ} \mathrm{C}} \\ & \times 100 \quad\end{aligned}$

TGA

Each sample (40 $\pm 10 \mathrm{mg}$ ) was individually placed on a high-temperature platinum pan and analysed using a TGA Q5000IR (TA Instruments, USA). The balance housing was kept at $40{ }^{\circ} \mathrm{C}$ under a nitrogen atmosphere while the sample chamber was purged with air at a flow rate of $25 \mathrm{~mL} / \mathrm{min}$. The heating rate was $20{ }^{\circ} \mathrm{C} / \mathrm{min}$ from room temperature to $150{ }^{\circ} \mathrm{C}$ followed by an isothermal period of $30 \mathrm{~min}$ to remove all moisture. The second heating $\left(20^{\circ} \mathrm{C} / \mathrm{min}\right)$ was to $550{ }^{\circ} \mathrm{C}$, where the temperature was again held for $30 \mathrm{~min}$ to ensure complete combustion of all organic matter and no further weight loss. The final heating, again at $20{ }^{\circ} \mathrm{C} / \mathrm{min}$, was to $950{ }^{\circ} \mathrm{C}$ with an isothermal period of $30 \mathrm{~min}$ to ensure that all carbonates in the sample were thermally degraded (Konare et al. 2010; Heiri et al. 2001; Bengtsson and Enell 1986).

\section{Results}

To obtain the LOI results, sample weights were accurately recorded to $0.0001 \mathrm{~g}$ prior to and after each heating stage. These weights were used to calculate the results by applying them to Eqs. 1 and 2. The TGA results were processed using Universal Analysis software (TA Instruments, UA, v5.5.24) to calculate the loss in mass between the isothermal stages of the method, as detailed in the methods section. Examples of the TGA curves obtained are shown in Figs. 1 and 2. LOI and TGA results for core ELF002 and ELF009 sediments are shown in Tables 2 and 3 , respectively.

\section{Discussion}

\section{Comparison of LOI and TGA}

For each sediment component analysed (i.e. organic matter and carbonate content), an unpaired t-test with 18 degrees of freedom $(d f=18)$ was applied with $95 \%$ confidence level $(p=0.05)$, to compare differences between means from application of each method to each core. Our null hypothesis was that "there is no statistically significant difference between mean values produced by the TGA and LOI methods" (Whitley and Bell 2002; Miller and Miller 2010).

With respect to organic matter content measured by the LOI and TGA methods, the calculated t-values for means are less than the critical t-values (Tables 2, 3), hence the null hypothesis could not be rejected. This indicates that the LOI and TGA techniques yielded indistinguishable organic matter results. 


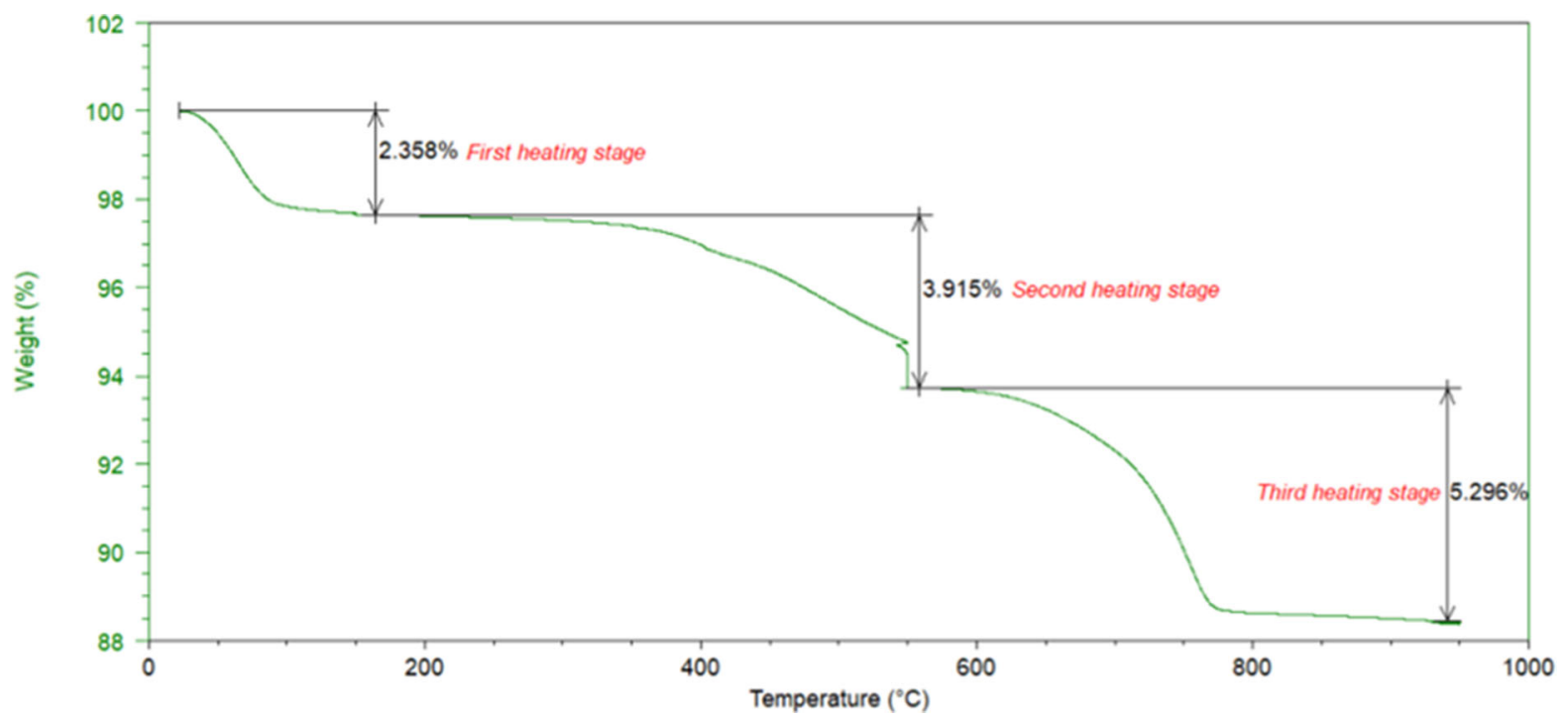

Fig. 1 Representative TGA curve from sample ELF002, illustrating three transitions

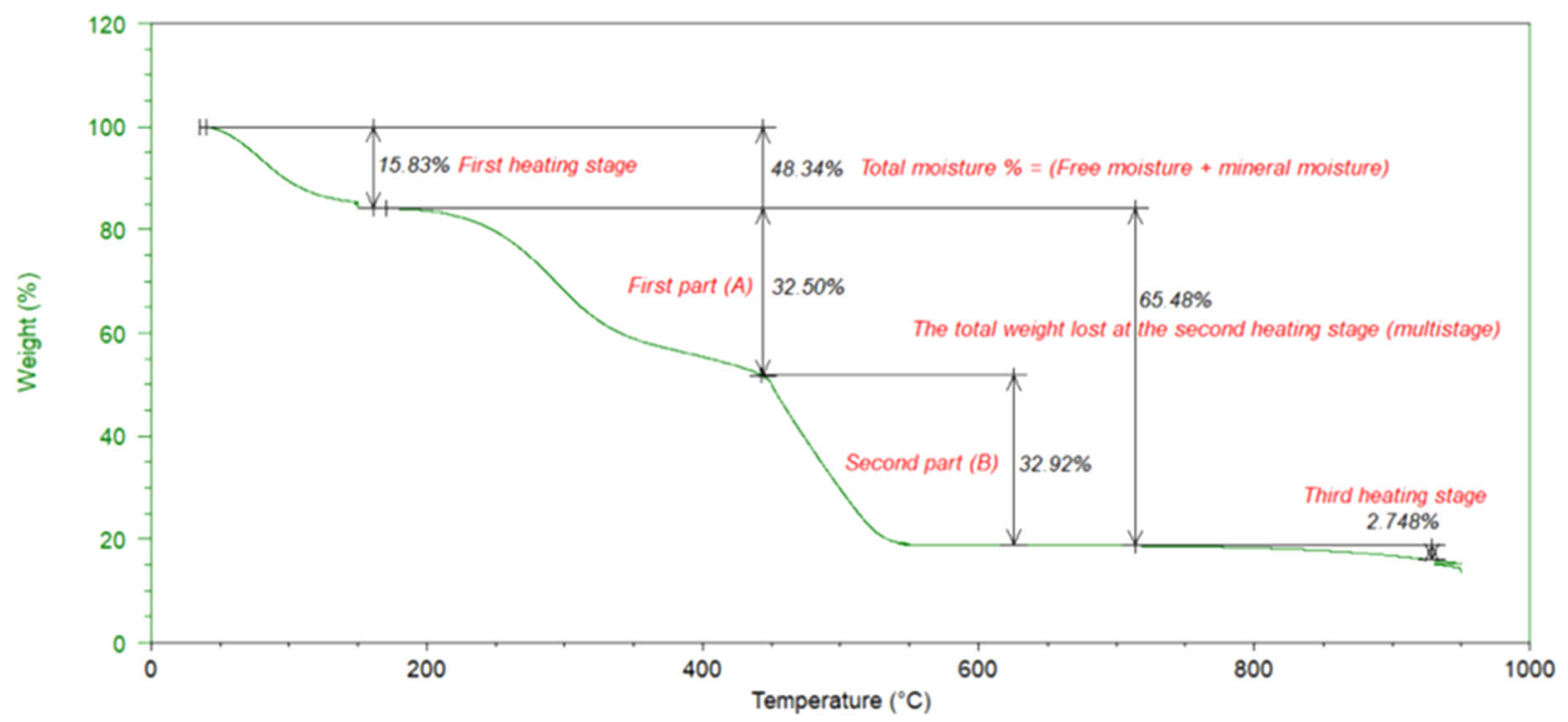

Fig. 2 Representative TGA curve from sample ELF009, illustrating four transitions

Mean carbonate content in the sediment samples from ELF002, measured by the two techniques, returned a t-value lower than the critical t-value (Table 2). As a consequence, the null hypothesis could not be rejected, and indicates that for this sediment type, the LOI and TGA methods yield indistinguishable carbonate results. For sample ELF009, the calculated t-value, 2.97, is higher than the critical t-value of 2.10 (Table 3), and we thus rejected the null hypothesis. This indicated that the two approaches produced results that differ, perhaps related to the lower content of carbonate in the ELF009 samples.

Repeatability (within-run precision)

In both samples ELF002 and ELF009, for percent organic matter and carbonate content, both methods showed consistent precision and repeatability, i.e. very low standard deviations ( $\mathrm{SD} \leq 0.55)$, and small differences in means $(\mathrm{DM} \leq 0.50)$ (Tables 2,3$)$. 
Table 2 Organic matter and carbonate content in core ELF002 sediment, determined by TGA and LOI methods

\begin{tabular}{|c|c|c|c|c|c|c|}
\hline \multirow{2}{*}{$\begin{array}{l}\text { Core ELF002 } \\
\text { Methods }\end{array}$} & \multicolumn{2}{|c|}{ Organic matter $\%$} & \multicolumn{2}{|c|}{ Lost $\mathrm{CO}_{2} \%$} & \multicolumn{2}{|c|}{ Carbonate $\%\left(\mathrm{CO}_{2} * 1.36\right)$} \\
\hline & TGA & LOI & TGA & LOI & TGA & LOI \\
\hline Run one & 3.92 & 4.20 & 5.30 & 5.27 & 7.21 & 7.17 \\
\hline Run two & 4.00 & 4.30 & 5.60 & 5.47 & 7.61 & 7.44 \\
\hline Run three & 3.91 & 4.30 & 5.31 & 5.44 & 7.22 & 7.40 \\
\hline Run four & 4.10 & 3.96 & 5.74 & 5.77 & 7.81 & 7.85 \\
\hline Run five & 4.01 & 4.37 & 5.31 & 5.24 & 7.22 & 7.13 \\
\hline Run six & 4.00 & 3.93 & 5.42 & 5.74 & 7.37 & 7.81 \\
\hline Run seven & 3.92 & 3.93 & 5.48 & 5.64 & 7.45 & 7.67 \\
\hline Run eight & 4.01 & 4.00 & 5.51 & 5.46 & 7.49 & 7.43 \\
\hline Run nine & 4.05 & 4.03 & 5.30 & 5.74 & 7.21 & 7.81 \\
\hline Run ten & 4.06 & 4.03 & 5.67 & 5.73 & 7.71 & 7.80 \\
\hline Mean & 4.00 & 4.11 & 5.46 & 5.55 & 7.43 & 7.55 \\
\hline Range & 0.19 & 0.44 & 0.44 & 0.53 & 0.60 & 0.72 \\
\hline Difference in means & 0.11 & & 0.09 & & 0.12 & \\
\hline Standard deviation & 0.06 & 0.17 & 0.16 & 0.20 & 0.22 & 0.27 \\
\hline Two sample t-test (unpaired) & \multicolumn{2}{|c|}{$\begin{array}{l}\text { Unpaired } \mathrm{t}(18)=1.86 \\
\quad p=0.088\end{array}$} & \multicolumn{2}{|c|}{$\begin{array}{l}\text { Unpaired } \mathrm{t}(18)=1.05 \\
\qquad p=0.31\end{array}$} & \multicolumn{2}{|c|}{$\begin{array}{l}\text { Unpaired } \mathrm{t}(18)=1.14 \\
\qquad p=0.29\end{array}$} \\
\hline Critical t-value & \multicolumn{2}{|l|}{2.10} & \multicolumn{2}{|l|}{2.10} & \multicolumn{2}{|l|}{2.10} \\
\hline
\end{tabular}

Table 3 Organic matter and carbonate content in core ELF009 sediment, determined by TGA and LOI methods

\begin{tabular}{|c|c|c|c|c|c|c|}
\hline \multirow{2}{*}{$\begin{array}{l}\text { Core ELF009 } \\
\text { Methods }\end{array}$} & \multicolumn{2}{|c|}{ Organic matter $\%$} & \multicolumn{2}{|c|}{ Lost $\mathrm{CO}_{2} \%$} & \multicolumn{2}{|c|}{ Carbonate $\%\left(\mathrm{CO}_{2} * 1.36\right)$} \\
\hline & TGA & LOI & TGA & LOI & TGA & LOI \\
\hline Run one & 32.92 & 32.44 & 2.75 & 2.53 & 3.74 & 3.44 \\
\hline Run two & 32.68 & 32.60 & 3.05 & 2.70 & 4.15 & 3.67 \\
\hline Run three & 32.72 & 32.87 & 3.59 & 2.63 & 4.88 & 3.58 \\
\hline Run four & 32.95 & 32.81 & 2.94 & 2.73 & 4.00 & 3.71 \\
\hline Run five & 32.69 & 32.80 & 3.62 & 2.70 & 4.92 & 3.67 \\
\hline Run six & 32.86 & 32.71 & 2.54 & 2.80 & 3.45 & 3.81 \\
\hline Run seven & 33.01 & 32.87 & 3.63 & 2.70 & 4.93 & 3.67 \\
\hline Run eight & 33.25 & 32.60 & 3.03 & 2.73 & 4.12 & 3.71 \\
\hline Run nine & 32.15 & 32.80 & 2.81 & 2.73 & 3.82 & 3.71 \\
\hline Run ten & 32.87 & 32.60 & 2.71 & 2.73 & 3.68 & 3.71 \\
\hline Mean & 32.81 & 32.71 & 3.07 & 2.70 & 4.17 & 3.67 \\
\hline Range & 1.10 & 0.43 & 1.09 & 0.27 & 1.48 & 0.37 \\
\hline Difference in means & 0.10 & & 0.37 & & 0.50 & \\
\hline Standard deviation & 0.28 & 0.14 & 0.41 & 0.07 & 0.55 & 0.10 \\
\hline Two sample t-test (unpaired) & \multicolumn{2}{|c|}{$\begin{array}{l}\text { Unpaired } \mathrm{t}(18)=0.98 \\
\quad p=0.34\end{array}$} & \multicolumn{2}{|c|}{$\begin{array}{l}\text { Unpaired } \mathrm{t}(18)=2.79 \\
\quad p=0.019\end{array}$} & \multicolumn{2}{|c|}{$\begin{array}{l}\text { Unpaired } \mathrm{t}(18)=2.97 \\
\quad p=0.019\end{array}$} \\
\hline Critical t-value & \multicolumn{2}{|l|}{2.10} & \multicolumn{2}{|l|}{2.10} & \multicolumn{2}{|l|}{2.10} \\
\hline
\end{tabular}


Multistage decomposition of samples from cores ELF002 and ELF009

During TGA analysis, all 10 samples from core ELF002 produced a curve with three clear transitions, associated with loss of free moisture, organic matter and carbonate (Fig. 1). In contrast, all 10 samples from core ELF009 produced a multistage decomposition in the second heating stage, from 150 to $550{ }^{\circ} \mathrm{C}$ (Fig. 2). This multistage response was divided into parts A \& B (Fig. 2), in which there are two weight losses from two different decompositions. The temperature range for part A was $173-367{ }^{\circ} \mathrm{C}$, and the temperature range for part B was $387-560{ }^{\circ} \mathrm{C}$. The temperature range of the organic matter ignition from ELF002 was between 384 and $563{ }^{\circ} \mathrm{C}$. This matches well with the temperatures in part B of core ELF009 and represents the ignition of organic matter. Therefore, part $\mathrm{A}$ in ELF009 represents loss of a different sample component, which occurred at temperatures between those responsible for loss of free moisture and organic matter. One possibility is mineral dehydration, which requires temperatures between 100 and $380{ }^{\circ} \mathrm{C}$ (Hoogsteen et al. 2015; Lopes et al. 2001). This range includes parts of the first (ambient to $150{ }^{\circ} \mathrm{C}$ ) and second LOI heating stages $\left(150-550{ }^{\circ} \mathrm{C}\right)$. It is therefore possible that water bound in minerals contributed to the LOI values attributed to moisture and organic matter, and explains why the LOI and TGA methods yielded statistically indistinguishable results for this sample.

\section{Conclusions}

Principles that underlie the two thermal methods (LOI and TGA) for analysis of sediment composition are similar. Both involve measurement of changes in sample weight as a function of temperature and duration (Abbot 2005; Çaylı and Küsefoğlu 2008). Two sediment samples from the North Sea were used to compare LOI and TGA results-ELF002, a sample with relatively low organic content, and ELF009, a sample with relatively high organic content. The experiment yielded the following conclusions:

1. TGA uses an instrument that carries out the analysis automatically, with less chance for human measurement error and less time required.
The ignition process can be monitored in real time and results can be presented in a TGA curve (Figs. 1, 2).

2. TGA is an appropriate instrument for small samples and provides stable results with samples as small as $40 \mathrm{mg}$.

3. Although much cheaper, the LOI method provides information only for specific preselected temperatures and takes much more time.

4. TGA and LOI both yield consistent repeatable results for determination of organic matter and carbonate content.

5. TGA provides details about the temperatures at which mass is lost, which are not possible with LOI. This may enable the user to identify other temperature-associated changes in the sediment, such as mineral dehydration.

In summary, we conclude that TGA can be used instead of LOI as a method to study sediment samples, and it is highly recommended for determination of organic matter and carbonate content in sediments. TGA is the preferred method in cases for which sample quantity is limited.

Acknowledgements We thank Dr. Bill Hale for comments on an early draft of this paper. Sediments used in this study were provided through the European Union's Horizon 2020 Research and Innovation Programme (Project no. 670518). We thank Dr. Martin Bates for assistance with sampling and storing information. Mohammed Bensharada thanks the Libyan Ministry of Higher Education for funding his $\mathrm{PhD}$.

Open Access This article is licensed under a Creative Commons Attribution 4.0 International License, which permits use, sharing, adaptation, distribution and reproduction in any medium or format, as long as you give appropriate credit to the original author(s) and the source, provide a link to the Creative Commons licence, and indicate if changes were made. The images or other third party material in this article are included in the article's Creative Commons licence, unless indicated otherwise in a credit line to the material. If material is not included in the article's Creative Commons licence and your intended use is not permitted by statutory regulation or exceeds the permitted use, you will need to obtain permission directly from the copyright holder. To view a copy of this licence, visit http://creativecommons.org/licenses/by/4.0/.

\section{References}

Abbott M (2005) Loss on Ignition (LOI) procedures. Standard Operating Procedures. University of Pittsburgh, Pittsburgh 
Ben-Dor E, Banin A (1989) Determination of organic matter content in arid-zone soils using a simple "loss-on-ignition" method. Commun Soil Sci Plan 20:1675-1695

Bengtsson L, Enell M (1986) Chemical analysis. In: Berglund BE (ed) Handbook of holocene paleoecology and paleohydrology. Wiley, Chichester

Çaylı G, Küsefoğlu S (2008) Increased yields in biodiesel production from used cooking oils by a two step process: comparison with one step process by using TGA. Fuel Process Technol 89:118-122

Charsley E, Price D, Hunter N, Gabbott P, Kett V, Gaisford S, Priestley I, Duncan J, Royall P, Scowen I (2019) Principles of thermal analysis and calorimetry. Spec Publ RSC, London

Fan M, Brown RC (2001) Comparison of the loss-on-ignition and thermogravimetric analysis techniques in measuring unburned carbon in coal fly ash. ISO4 15:1414-1417

Gaffney V, Allaby R, Bates R, Bates M, Ch'ng E, Fitch S, Garwood P, Momber G, Murgatroyd P, Pallen M (2017) Doggerland and the lost Frontiers project (2015-2020). Under the Sea: Archaeology and Palaeolandscapes of the Continental Shelf. Springer, Cambridge

Gaffney V, Fitch S, Bates M, Ware RL, Kinnaird T, Gearey B, Hill T, Telford R, Batt C, Stern B, Whittaker J, Davies S, Sharada MB, Everett R, Cribdon R, Kistler L, Harris S, Kearney K, Walker J, Muru M, Hamilton D, Law M, Finlay A, Bates R (2020) Allaby RG (2020) Multi-proxy characterisation of the Storegga Tsunami and its impact on the Early Holocene landscapes of the southern North Sea. Geosciences 10:270

Heiri O, Lotter AF, Lemcke G (2001) Loss on ignition as a method for estimating organic and carbonate content in sediments: reproducibility and comparability of results. J Paleolimnol 25:101-110

Hoogsteen MJJ, Lantinga EA, Bakker EJ, Groot JCJ, Tittonell PA (2015) Estimating soil organic carbon through loss on ignition: effects of ignition conditions and structural water loss. Eur J Soil Sci 66:320-328

Konare H, Yost R, Doumbia M, Mccarty G, Jarju A, Kablan R (2010) Loss on ignition: measuring soil organic carbon in soils of the Sahel. Afr J Agr Res 5:3088-3095

Lopes H, Trindade T, Gulyurtlu I, Cabrita I (2001) Characterisation of FBC ashes from co-combustion of coal with oily residues. Fuel 80:785-793

Miller J, Miller JC (2010) Statistics and chemometrics for analytical chemistry. Prentice Hall, New Jersey

Santisteban JI, Mediavilla R, Lopez-Pamo E, Dabrio CJ, Zapata MBR, García MJG, Martínez-Alfaro CS, PE, (2004) Loss on ignition: a qualitative or quantitative method for organic matter and carbonate mineral content in sediments? J Paleolimnol 32:287-299

Virkanen J, Korhola A, Tikkanen M, Blom T (1997) Recent environmental changes in a naturally acidic rocky lake in southern Finland, as reflected in its sediment geochemistry and biostratigraphy. J Paleolimnol 17:191-213

Whitley E, Ball J (2002) Statistics review 2: Samples and populations. Crit Care 6(2):1-6

Publisher's Note Springer Nature remains neutral with regard to jurisdictional claims in published maps and institutional affiliations. 